ANGELIKA MOSKAL

(1) HTTP://ORCID.ORG/ 0000-0002-3862-2863

Uniwersytet Marii Curie-Skłodowskiej w Lublinie

e-mail: angelikamoskal93@wp.pl

\title{
"Cóż, że mnie śmierć wymaże z żyjącego świata, lepiej przeżyć wieki, aniżeli lata" - oświeceniowa reinterpretacja podania o Wandzie według Adama Rościszewskiego
}

\begin{abstract}
„Well, that death will erase me from the living world, it is better to live ages than years" - Enlightenment Reinterpretation of the Legend about Wanda According to Adam Rościszewski
\end{abstract}

Among the Slavic stories from the Lesser Poland cycle, story about Wanda left its mark in Polish literature the most. From the moment Tekla Łubieńska won the national tragedy competition in 1803, the fashion began for texts about the legendary queen and a period of increased activity of writers creating dramas based on the Polish history. Among the series of tragedies based on the mention of Krak's daughter Wanda, Adam Rościszewski deserves special attention. The article focuses on Rościszewski's reinterpretation of the history of Wanda, which is distinguished by the way of portraying the Kraków ruler and the modifications made to the love thread introduced by Łubieńska.

Keywords: Adam Rościszewski, Wanda (legendary queen), classicist tragedy, legend

Słowa kluczowe: Adam Rościszewski, Wanda (legendarna królowa), tragedia klasycystyczna, legenda

Spośród słowiańskich podań z cyklu małopolskiego ${ }^{1}$ historia o Wandzie najmocniej odcisnęła swoje piętno w polskiej literaturze. Od momentu wygrania przez

${ }^{1}$ Do cyklu małopolskiego zalicza się podania o Kraku, Wandzie oraz Walgierzu z Tyńca i Wisławie z Wiślicy. J. Maślanka, Literatura a dzieje bajeczne, Warszawa 1984, s. 6. 
Teklę Łubieńską w 1803 roku konkursu ${ }^{2}$ na tragedię o tematyce narodowej ${ }^{3}$ rozpoczęła się moda na utwory o legendarnej królowej ${ }^{4}$ oraz okres wzmożonej aktywności pisarzy tworzących dramaty oparte na polskich dziejach ${ }^{5}$. Wydaje się, że dopiero dzięki pisarce dostrzeżono potencjał artystyczny podania o córce Kra$\mathrm{ka}^{6}$. Zapewne dzieło Łubieńskiej miałoby o wiele mniejszy wpływ na literaturę, gdyby nie fakt, że zostało bardzo ciepło przyjęte zarówno przez krytyków, jak i przez społeczeństwo ${ }^{7}$. O wystawienie sztuki na scenie mocno zabiegał Ludwik Osiński, którego autorka poprosiła o ocenę swojego utworu. Dzięki jego rekomendacjom Wanda została wystawiona 17 kwietnia 1807 roku. Tragedię przyjęto entuzjastycznie - 19 i 26 kwietnia została odegrana ponownie 9 , co było swego rodzaju fenomenem. Bardzo rzadko zdarzało się, by tragedie zyskiwały aż taką popularność, która projektowała ich powtórne odegranie ${ }^{10}$.

Za wzrostem zainteresowania córką Kraka stał nie tylko sukces tragedii Łubieńskiej, lecz również tendencje kształtowania literatury w konwencjach narodowych, nowe funkcje zaczęto przypisywać historii, w tym i dziejom bajecznym $^{11}$. Za wszelką cenę starano się ocalić poczucie narodowej wspólnoty, które

${ }^{2}$ Należy zaznaczyć, że utwór został zgłoszony bez wiedzy autorki, co nie spotkało się z jej aprobatą, choć ostatecznie przysporzyło jej sławy. J. Ujejski, Wstęp [w:] T. Łubieńska, Wanda, Warszawa 1927, s. 5-6.

${ }^{3}$ Konkurs ten został ogłoszony przez Towarzystwo Przyjaciół Nauk, które mocno angażowało się w badania historyczne. Na zebraniach Jan Albertrandi podnosił między innymi konieczność podjęcia prac nad niedokończonym pierwszym tomem Historii narodu polskiego Adama Naruszewicza, który miał zawierać opis narodowej „starożytności”. Zob. D. Ratajczak, Wstęp [w:] Polska tragedia neoklasycystyczna, Wrocław 1988, s. XLIX-L; J. Maślanka, Stowiańskie mity historyczne w literaturze polskiego Oświecenia, Wrocław 1968, s. 113-114.

${ }^{4}$ Podanie o Wandzie było opracowywane literacko także w dramatach Euzebiusza Słowackiego, Jana Ignacego Dembowskiego, Adama Rościszewskiego, Franciszka Wężyka, Jana Maksymiliana Fredry, nieukończonym Zygmunta Krasińskiego oraz Cypriana Kamila Norwida (w każdym z tych przypadków tytuł brzmiał: Wanda).

5 Trzeba dodać, że dramaty opierające się na historii narodowej powstawały już wcześniej, na przykład w 1779 roku Józef Wybicki napisał Zygmunta Augusta, w 1792 roku Franciszek Karpiński stworzył Judytę, królowa polska. Najwięcej jednak utworów o tematyce historycznej powstało właśnie w okresie porozbiorowym. Por. J. Ujejski, op. cit., s. 3.

${ }^{6}$ Warto przypomnieć, że Łubieńska swoim utworem otwarła drogę nie tylko licznym dramatom poświęconym Wandzie. Dzięki niej doceniona została także twórczość kobiet, do których w jednym ze swoich listów Alojzy Orchowski zwracał się następującymi słowami: „Wyście w duszach waszych pielęgnowały uczucia, jakiemi autorka Wandy powszechność narodową przejęła, zadziwiła, nieśmiertelną wdzięczność z najtrwalszym zjednała szacunkiem” (J. Ujejski, op. cit., s. 9). Można zatem domniemywać, że dzięki legendarnej królowej zaczęto dostrzegać rolę kobiet w podtrzymywaniu tożsamości narodowej.

${ }^{7}$ Ujejski wspomina, że wyrazem uznania dla pisarki miał być między innymi zadedykowany jej przez Ludwika Osińskiego wiersz pt. Do JW. Hrabiny Tekli z Bielińnskich Łubieńskiej w dzień jej imienin dn. 23 września 1808, w którym wspomina on o Wandzie w tych słowach: „Od tylu wieków ta ziemia nie miała / Komu powierzyć berła polskiej sceny / Aż wreszcie «Wanda» Tobie je oddała”. Ibid., s. 7.

${ }^{8}$ Ibid., s. 6.

${ }^{9}$ Sukces Wandy powtórzyły później: w 1810 roku Gliński Franciszka Wężyka; i w 1816 roku Ludgarda Ludwika Kropińskiego; oraz Barbara Radziwitłówna Alojzego Felińskiego. Ibid., s. 8.

${ }^{10}$ Ibid.

11 „Dzieje bajeczne” to formuła zaczerpnięta z tytułu książki Juliana Maślanki. Oznacza czasy przedhistoryczne. 
współtworzyła kultura, język oraz przeszłość ${ }^{12}$. Wysiłki zaborców zmierzające do przekłamania historii Polski i utrudnień w zdobywaniu realnej wiedzy na jej temat jedynie spotęgowały ruch historiograficzny ${ }^{13}$. Zgłębianie dawnych czasów stało się tym samym jedną z form walki, w którą czynnie angażowali się literaci. Posiadając znaczący wpływ na życie społeczne, dzięki swoim dziełom mieli upowszechniać wiedzę na temat przeszłości oraz pomagać lepiej ją zrozumiećl ${ }^{14}$. W podaniach (które starano się przede wszystkim traktować jako jeden z elementów świadomości narodowej ${ }^{15}$, nie zaś rzetelne źródło historyczne) szukano postaci mogących stanowić inspirację do kreowania postaw przeciwstawnych losowi. Nic dziwnego, że Wanda odrzucająca zaloty niemieckiego księcia, a następnie mężnie odpierająca wojska najeźdźcy, by na koniec (zgodnie z najpopularniejszą wersją podania ${ }^{16}$ ) poświęcić życie dla dobra własnych poddanych, stała się niezwykle nośnym symbolem. Bardzo łatwo można było odnieść dzieje córki Kraka do wieku XIX i dokonać ich aktualizacji. Wanda tym samym zaczęła uosabiać ideał osoby o nieugiętym duchu, niepoddającej się w obliczu zagrożenia, lecz walczącej o ideały i tożsamość narodową, gotowej do najwyższych poświęceń w imię dobra ogółu.

Przy uwzględnieniu wyżej opisanych nastrojów społecznych, nie powinno stanowić zaskoczenia to, że po Łubieńskiej dramaturdzy tak żywo zainteresowali się podaniem o królowej „,co Niemca nie chciała” i stworzyli szereg utworów opartych na tej narracji. Choć w dużej mierze zachowywano najważniejsze elementy oryginalnej fabuły oraz główną oś wydarzeń, samą postać Wandy pisarze już różnorodnie interpretowali. Większość dramaturgów wykorzystywała wprowadzony przez Teklę Łubieńską wątek romansowy ${ }^{17}$, który nie ma potwierdzenia

12 Wagę narodowej przeszłości dla społeczeństwa podkreśla między innymi Jacek Banaszkiewicz: „By rzec najkrócej, do skarbca historii początkowej wkłada zbiorowość wszystkie kosztowności, jakie ma. Deponuje tam ważne dla kultury i racji bytu kraju wartości, zwyczaje, ryty. Do «narodowej» rekwizytorni wprowadza wszystkich bohaterów, dzięki którym wspólnota powstała i broniła swojej odrębności”. J. Banaszkiewicz, Polskie dzieje bajeczne mistrza Wincentego Kadtubka, Wrocław 1998, s. 5.

13 A. Wierzbicki, Historiografia polska doby romantyzmu, Wrocław 1999, s. 22.

14 K. Bartkiewicz, Obraz dziejów ojczystych w świadomości historycznej w Polsce doby Oświecenia, Poznań 1979, s. 12.

15 Ibid., s. 339-340. Obecnie również eksponuje się przede wszystkim tę rolę podań. Trafnie ujął to Andrzej Zieliński: „Legendy oraz przekazy historyczne, najstarsze zapisy kronikarskie służą budowaniu i umacnianiu tożsamości narodowej, identyfikacji z minionymi pokoleniami. Od przybliżania najdawniejszych dziejów zawsze powinny się zaczynać lekcje patriotyzmu". A. Zieliński, Czy smok wawelski byt człowiekiem? Historia polskich legend, Warszawa 2016, s. 9.

16 Piszę „najpopularniejszą”, ponieważ przekazy kronikarskie podają różne warianty zakończenia opowieści o Wandzie. Wincenty Kadłubek nie wspomina o samobójczej śmierci - według jego relacji królowa panowała jeszcze długo po pokonaniu niemieckiego wojska. Niestety nie pozostawiła po sobie następcy, co doprowadziło później do chaosu w kraju. Zarówno Jan Długosz, jak i Kronika wielkopolska podają, że po odniesionym zwycięstwie Wanda podpisała rozejm z pozostałymi panami niemieckimi, a następnie wyprawiła uroczystości na cześć bogów. Po ich zakończeniu Wanda postanawia poświęcić własne życie na ofiarę dziękczynną i rzuca się do Wisły. W kronice Marcina Bielskiego królowa również popełnia samobójstwo, dopełniając tym samym ślubów złożonych bogom, jednak czyni to bezpośrednio po zwycięstwie nad Rygierem.

17 Ujejski dowodzi, że wprowadzenie wątku miłości Wandy i Rytygiera nie był wyłącznie pomysłem Łubieńskiej. Miała ona inspirować się literaturą niemiecką, w której podanie o córce Kraka zostało 
w podaniu. Wśród szeregu różnorodnych utworów na szczególną uwagę zasługuje Wanda Adama Rościszewskiego - zarówno ze względu na to, w jaki sposób została w nim sportretowana krakowska władczyni, jak i z powodu modyfikacji dokonanych w wątku miłosnym.

$\mathrm{Na}$ wstępie warto zerknąć na przemyślenia autora zawarte w poprzedzającej utwór przedmowie Do czytelnika, które dotyczą między innymi historyczności Wandy. Można wnioskować, że Rościszewski posiadał dobrą orientację w istniejących opracowaniach dotyczących dziejów przedhistorycznych. Wspomina nazwiska Adama Naruszewicza ${ }^{18}$ oraz Tadeusza Czackiego, podsumowując krótko opinię obu badaczy na temat wiarygodności opowieści o królowej ${ }^{19}$. Znajome mu były także źródła kronikarskie, a z pewnością kroniki Galla Anonima i Wincentego Kadłubka. Dramaturg przyjmuje treści podania bardzo ostrożnie - ani nie neguje jego prawdziwości, ani otwarcie nie mówi, że wierzy przekazom:

Mnie się zdaje, że tak wielką odległość zdarzeń, od oświeceńszych Słowiańskich wieków, od tej mówię epoki, gdzie Dytmar Gallus i później Kadłubek pisać zaczynali, którzy wszyscy na 5. lub 6. wieków po Wandzie żyli; ani utrzymywać, ani zaprzeczać z pewnością nie można $^{20}$.

Rościszewski dzieli się powodami, które skłoniły go do przyjęcia na warsztat tego tematu. Jak wspomina, była to jego pierwsza tragedia. Podanie o Wandzie uważał za atrakcyjne z dwóch względów. Po pierwsze, stanowiła go materia zaczerpnięta z dziejów narodowych ${ }^{21}$. Po drugie, urzekła go sama historia, którą, jak wspominał, nie tylko on uznał za odpowiednią do zbudowania na niej dzieła dramaturgicznego. Jak można się domyślać, Rościszewski takimi oto słowy mówił właśnie o Wandzie Łubieńskiej: „,[...] a lubo nie jest myślą moją walczyć o pierwszeństwo z naszą Des Houlierres Polską, która już Tragedyą Wandy zbogaciła scenę Warszawską" 22 .

Autor otwarcie przyznaje się do wprowadzonych przez siebie zmian $\mathrm{w}$ fabule podania. Thumaczy ten fakt tym, że tworzy „Tragedyę, nie Historię”. Zachowuje jedynie najważniejszych bohaterów oraz zdarzenia, pozwalając sobie na licencję

znacznie wcześniej wykorzystane jako materiał na dramat. W 1794 roku miał powstać utwór pt. Wanda Fürstin von Polen, oder die unglückliche Heirat autorstwa von G[ottlieba] F[riedricha] Wurrwitza, a w 1804 roku powieść zatytułowana Wanda, Fürstin von Krakau oder die Opfer der Liebe. Ujejski twierdzi, że polskiej autorce niemieckie utwory musiały być znane. Zob. J. Ujejski, op. cit., s. 16-17.

${ }^{18}$ Naruszewicz zanegował historyczność Kraka i Wandy, nie odrzucał jednak zupełnie dziejów bajecznych, twierdząc, że mogą zawierać w sobie jakiś pierwiastek prawdy. Zob. K. Bartkiewicz, op. cit., s. 80; por. też A.F. Grabski, Myśl historyczna polskiego oświecenia, Warszawa 1976, s. 162.

19 A. Rościszewski, Do czytelnika [w:] A. Rościszewski, Wanda, Kraków 1810, s. 1.

${ }^{20}$ Ibid., s. 1.

${ }^{21}$ Jak widać, sposób myślenia Rościszewskiego wpisywał się w ówczesne konwencje literackie. Podobne zdanie miał Adam Kazimierz Czartoryski: „Źle by chwycił myśl moją [...], kto by rozumiał, że z starożytności chciałbym mieć jedynie wybrane argumenta tragedii. I owszem, jest to moje zdanie, że przypadki wzięte z historii narodowej wielcy ludzie krajowi wyprowadzeni na scenę, domowe przykłady poruszą, przywiążą, skutkować bardziej będą na umyśle spektatora jak obce". A.K. Czartoryski, Przedmowa do Panny na wydaniu [w:] idem, Teatr Narodowy 1765-1794, red. J. Kott, Warszawa 1967, s. 137.

${ }^{22}$ A. Rościszewski, Do czytelnika, op. cit., s. 3. 
w zakresie pozostałych szczegółów: „wziąwszy jedną osobę, która istotę rzeczy stanowi i jedno zdarzenie, które jest najważniejsze, o resztę ni mam przyczyny się pytać, tylko plan mój mając przed oczyma, nie księgi dziejopisów”23. Rościszewski tłumaczy prawo do takich innowacji tradycją: już od samego początku pisarze w pełni świadomie popełniali nieścisłości historyczne dla uzyskania lepszego efektu końcowego.

Jeśli chodzi o gatunek, mamy tutaj do czynienia, jak w przypadku Łubieńskiej, z tragedią klasycystyczną 24 . Sugeruje to już samo słowo wstępu, w którym autor zwraca uwagę na liczne przepisy, jakie obowiązywały go w trakcie pisania $^{25}$. Wskazuje ponadto na twórców klasycznych poetyk (m.in. Arystotelesa), nie pomija także rodzimych krytyków i teoretyków, którzy niezwykle surowo oceniali dzieła właśnie pod względem przestrzegania prawideł pisarskich.

Utwór, podobnie jak dzieło laureatki konkursu, zachowuje charakterystyczną, pięcioaktową kompozycję ${ }^{26}$. Ekspozycja jest tutaj znacznie krótsza, niż było to w przypadku Wandy Łubieńskiej ${ }^{27}$. Składa się na nią monolog królowejej ${ }^{28}$ z którego można wnioskować o konflikcie wewnętrznym głównej bohaterki. Tak jak to było u Łubieńskiej, przyczyną rozterek Wandy jest jej miłość. Rościszewski jednak ukochanym królowej czyni nie Rytygiera, lecz polskiego rycerza Przemysława. O tym, jakie konsekwencje ta zmiana miała zarówno dla całej fabuły, jak i samej bohaterki, będzie jeszcze mowa.

23 Ibid., s. 2.

24 Zainteresowanie tym gatunkiem znacznie wzrosło po rozbiorach. Zob. B. Czwórnóg-Jadczak, Klasyk aż do śmierci. Twórczość literacka Franciszka Wężyka, Lublin 1994, s. 44-45.

25 W klasycyzmie tragedię uznawano za gatunek stojący najwyżej w literackiej hierarchii, dlatego została ona obwarowana licznymi regułami (zob. D. Ratajczak, Wstęp, op. cit., s. LXXIV-LXXXVII). O szeregu zasad, do których należało się zastosować, wspominał między innymi Antoni Hoffman: „Znam ja te wielkie trudności, te uparte przeszkody, które w pisaniu dzieł podobnych zwyciężyć potrzeba [...]. Nie dosyć jest umieć doskonale ojczystą mowę, znać reguły i logikę; trzeba jeszcze do tego i gust wielki posiadać, żeby ocenić myśli i zdania, obrazy i czynności, które bystry dowcip hojnie utwarza, a z których rozsądny pisarz czyni wybór nie obfity”. A. Hoffman, Heligunda, Warszawa 1929, s. 73.

26 „Akt pierwszy służy do wyłożenia rzeczy, miejsca, a częstokroć i czasu, w którym się sprawa dzieje. Pokazują się w nim aktorowie podrzędniejsi, albo przynajmniej wzmianka o nich bywa. Drugi akt objaśnia stopniami, co się przedsiębierze. W trzecim akcie najwięcej trudności przybywa i rozmaite pomieszanie zachodzi. Czwarty akt, coraz większe zawikłania sprawując, całą rzecz ku końcowi kieruje. Piąty akt po różnych trudnościach rozwiązuje dramatyczny węzeł”. F.N. Golański, O wymowie i poezji, Wilno 1808, s. 534.

${ }^{27}$ U Łubieńskiej mamy do czynienia z dialogiem, który miał przekazać widzom wszystkie niezbędne szczegóły. Taka forma była charakterystyczna dla francuskiej tragedii klasycznej. Zob. J. Ujejski, op. cit., s. 23.

28 Początkowa wypowiedź jednak nie uściśla tego, co działo się z rodziną królewską oraz z Wandą, zanim objęła rządy, a co wyraźnie precyzuje Łubieńska. Rościszewski jedynie raz w trakcie dialogu królowej z Rytygierem wykorzystuje motyw synów Kraka, w wypowiedzi księcia: ,[...] Oto masz jakie czucie me serce rozrania, / Co wzbudza me zapały, i me serce skłania, / Miałaś Braci, co poszli na wieczną zagładę; / Jeden zginął nieszczęściem, a drugi przez zdradę; / Ich pamięć zawsze w żywej oglądasz postaci. / Lecz niechaj ci przyjaciel trzyma miejsce Braci” (a. II, s. 1, ww. 45-50). Cytaty pochodzą z wydania: A. Rościszewski, Wanda, Kraków 1810. 
Jeśli chodzi o zachowanie ważnej dla tragedii klasycystycznej zasady trzech jedności ${ }^{29}$, w przypadku miejsca Rościszewski idzie śladem bardziej liberalnych teoretyków ${ }^{30}$. W jego Wandzie przestrzenią, w której rozgrywają się wydarzenia, jest nie tylko zamek królewski, lecz także okolice Krakowa ${ }^{31}$, gdzie wojska Rytygiera rozbijają obóz, oraz znajdująca się nieopodal świątynia Jessy ${ }^{32}$. Zdarzenia zamykają się w ciągu jednego dnia. Jedność akcji również zostaje zachowana wszystko toczy się wokół Wandy, nie ma żadnych wątków pobocznych, na które zdecydowała się Łubieńska ${ }^{33}$. Częściowo respektowana jest zasada stosowności. Wydarzenia rozgrywające się na polu bitwy nie zostają bezpośrednio pokazane na scenie. Zamiast tego otrzymujemy szereg relacji poszczególnych bohaterów, którzy opowiadają o przebiegu walki. Przedstawione natomiast zostaje na samym końcu samobójstwo Wandy, czego nie było w utworze Łubieńskiej.

Rościszewski zachowuje punkt wyjścia akcji, jakim jest przybycie Rytygiera do Krakowa, które staje się katalizatorem wszystkich późniejszych wydarzeńn ${ }^{34}$. Wykorzystany zostaje główny szkielet fabularny podania: wojna między Polakami a Niemcami po odrzuceniu przez Wandę oświadczyn księcia. Autor pozwolił sobie na wprowadzenie elementów, które sprawiają, że całość staje się znacznie bardziej sensacyjna, niż pierwotnie projektowano. Dopisana została dworska intryga - przeciwko królowej i Przemysławowi zawiązują wspólnie z Germanami sojusz Wszewor z Arcykapłanem. Początkowo działania tej dwójki zmierzają do ślubu Wandy z Rytygierem, kiedy zaś kobieta nie zgadza się na ten mariaż, planują zamordować ją razem $\mathrm{z}$ ukochanym.

Ponieważ Rościszewski zdecydował się na modernizację wprowadzonego przez Łubieńską motywu, musiał wymyśleć inny powód, dla którego zakochani

${ }^{29}$ Zasada trzech jedności miała trzymać w ryzach wyobraźnię twórców, którzy nie mogli pozwolić sobie na wielowątkowość bądź rozbijanie akcji w czasie. Dzięki temu sztuki miały zachować przejrzystość. Początkowo stosowanie tej zasady wiązało się również z ograniczeniami scenicznymi, które nie pozwalały między innymi na zmianę dekoracji w trakcie trwania przedstawienia. W późniejszych latach jej przestrzeganie miało przede wszystkim służyć zwiększeniu prawdopodobieństwa opowiadanej historii. Również dzięki zachowaniu spójności dzieła oraz stworzeniu jednego, wyrazistego obrazu morał płynący z tragedii miał być łatwiejszy do wychwycenia i zapamiętania przez widownię.

${ }^{30}$ Między innymi Wężyk miejsce akcji tragedii rozszerzał o okolice miejscowości, w której zachodziły wydarzenia. Za: M. Szyjkowski, Dzieje nowożytnej tragedii. Typ pseudoklasyczny (16611831), Kraków 1920, s. 197.

${ }^{31}$ Podobnie czyni Łubieńska, która końcowe akty umiejscawia na tle dwóch obozów wojskowych w okolicy Krakowa.

${ }^{32}$ Bóstwo autor zapewne zaczerpnął od Długosza, który wspominał o nim w swojej kronice. Według kronikarza Słowianie mieli tak nazywać Jowisza. Imię Jesse (bądź Jesza), podobnie jak Łada, pochodzi w istocie z refrenów pieśni ludowych (zob. A. Gieysztor, Mitologia Stowian, oprac. A. Pieniądz, Warszawa 2006, s. 195-196). Rościszewski z panteonu Długosza musiał wybrać najpotężniejsze bóstwo, skoro zamierzał jego kapłana umieścić w najbliższym otoczeniu królowej.

${ }^{33}$ Oprócz wątku Wandy obserwujemy również losy porwanego za młodu przez Niemców Kaslerza, który wraca w rodzinne strony z wojskiem Rytygiera, by odnaleźć siostrę.

${ }^{34}$ Zawiązanie akcji zostało poprowadzone zgodnie z wytycznymi Czartoryskiego zalecającego, aby utwór rozpoczynał się w momencie pozornie kulminacyjnym, który miał być jednak odwlekany. Zabieg ten miał na celu przykucie uwagi widza. Por. M. Szyjkowski, op. cit., s. 48-49. 
nie mogą być razem ${ }^{35}$. Przez to zmienia się także jedna z wartości, między którymi córka Kraka musi dokonać wyboru. Jako że Przemysław nie jest cudzoziemcem, autor postanowił jako argumentu przeciw użyć ślubów czystości Wandy ${ }^{36}$. Królowa składa je zaraz na początku swojego panowania ${ }^{37}$. Nie poznajemy powodów takiego postępowania. Z treści utworu można wnioskować, że do takiego czynu popchnęła kobietę jej pobożność. Królową bowiem wyróżnia wyjątkowa bogobojność, którą miała przejawiać już od najmłodszych lat. Wanda, obawiając się gniewu bogów, będzie starała się robić wszystko, by ich zadowolić. Jej wiara jednak zostanie wykorzystana przeciwko niej przez Arcykapłana, który będzie starał się za jej pomocą manipulować władczynią:

[...] Wanda, za Rządów ojca, od życia początku,

Wiele czci dla świętego powzięła obrządku.

Ta władza namiestnicza w tym ubiorze strojnym,

Moc miała nad tej Księżny sercem bogobojnym.

I choć ją nie przybielił, ni zmarszczył wiek stary,

Dla czci swych poprzedników wiele miała wiary $[\ldots]$

(IV, s. 1, ww. 25-30)

Należy podkreślić, że Wanda składa przysięgę jeszcze przed spotkaniem Przemysława, czyli zanim tak naprawdę pozna siłę miłości i w pełni zrozumie, z czego decyduje się zrezygnować. Śluby w dalszych latach staną się przyczyną cierpień władczyni oraz jej rycerza. Rysuje się tutaj konflikt między pragnieniem zaznania szczęścia a narzuconymi wcześniej zobowiązaniami wobec wiary. Wydaje się, że jest to sprawa bardziej osobista niż państwowa - odwrotnie niż u Łubieńskiej, gdzie cały czas bardzo mocno akcentowany był aspekt polityczny dylematu Wandy. U Rościszewskiego zdecydowanie jest on słabiej akcentowany.

Również sposób portretowania królowej znacznie różni się od wyobrażenia Łubieńskiej - nie tylko wyeksponowaniem pobożności bohaterki. W chronologicznie pierwszej tragedii Wanda dopiero pod koniec, kiedy ma już świadomość, że jej rozstanie z Rytygierem jest nieuniknione, pozwala sobie na moment słabości. Zastanawia się wtedy nad abdykacją. Ostatecznie odrzuca ten pomysł, stawia-

35 Przypomnijmy - u Łubieńskiej głównym powodem było pochodzenie Rytygiera. Poddani Wandy nie zgadzali się na króla Niemca, bojąc się, że znacznie ograniczy on ich swobody obywatelskie oraz narzuci obcą wiarę. Wanda musiała zatem wybierać pomiędzy osobistym szczęściem a dobrem swojego ludu.

${ }^{36}$ Hanna Mortkowicz-Olczakowa wskazywała, że po takie rozwiązanie pisarze sięgali wówczas, kiedy brakowało w fabule wyrazistego konfliktu między obowiązkiem a miłością, co ma miejsce właśnie w przypadku utworu Rościszewskiego. Por. H. Mortkowicz-Olczakowa, Podanie o Wandzie. Dzieje watku literackiego, Warszawa 1927, s. 28.

${ }^{37}$ Motyw ślubów czystości Wandy jest obecny u Długosza oraz w Herbarzu Bartosza Paprockiego, którzy w ten sposób uzasadniali fakt, że królowa nie wstąpiła w stan małżeński. Długosz nie tłumaczył takiego postępowania, Paprocki natomiast pisał, że motywacją kobiety była chęć sprawowania niepodzielnej władzy w państwie: „[...] która nie chcąc pana mieć nad sobą, sama królestwem rządzić umyśliła, a chcąc w tem znać sobie, według wiary swej pogańskiej, Bogi życzliwe, czystość im ślubiła". Zob. B. Paprocki, Herby rycerstwa polskiego przez Bartosza Paprockiego zebrane i wydane r. p. 1584; wydanie Kazimierza Józefa Turowskiego, Kraków 1858, s. 14. 
jąc na pierwszym miejscu zobowiązania wobec swoich poddanych ${ }^{38}$. Ten moment kryzysu, po którym bohaterka wyłącznie mocniej utwierdza się w przekonaniu, że czyni słusznie, stawiając sprawy państwowe nad sercowe, podkreśla wielkość ofiary oraz szlachetność Wandy 39 . W przypadku utworu Rościszewskiego już pierwsze wersy pokazują rozpacz królowej. Kobieta skarży się na obowiązki, jakie wiążą się ze sprawowaniem władzy oraz na przysięgę:

Co mi po tych zaszczytach, i co mi po tronie,

Gdzie nikczemność przy blasku, więzy przy koronie.

Jakże są panowania nieznośne prawidła!

Ach! wierz mi, że mi moja dostojność obrzydła.

Kocham ja Przemysława, a moje kochanie

I z przysięgą bezżeństwa pewnie nieustanie.

Niechcę łamać przyrzeczeń stwierdzonych w świątyni,

Lecz mi ten przymus serca tron obierzłym czyni [...]

(I, s. 1, ww. 1-8)

Nieznajomość przyczyny, dla której Wanda zdecydowała się złożyć śluby czystości, sprawia, że jej tragizm wydaje się mniej wyrazisty, niż było to w przypadku bohaterki Łubieńskiej. W tym przypadku to córka Kraka i podejmowane przez nią decyzje, a nie nacisk ze strony społeczeństwa, są w większości przyczyną jej cierpień.

Pozostałe cechy charakteru sprawiają, że Wanda Rościszewskiego ma w sobie o wiele mniej królewskiego majestatu niż Wanda Łubieńskiej. Bohaterka sportretowana przez dramaturga jest przede wszystkim nieszczęśliwie zakochaną, odrobinę naiwną kobietą, którą część osób stara się wykorzystać w celu osiągnięcia własnych korzyści. Królowa uosabia głównie wdzięk oraz delikatnośćc ${ }^{40}$. W dramacie podkreśla się jej niezwykłą urodę $e^{41}$ oraz niewinność. Rola władczyni zostaje odsunięta na drugi plan. Podobnie jak to było w podaniu, Wanda zamierza początkowo stanąć na czele wojsk. Podjęcie takiej decyzji wskazywałoby na drzemiące w niej męstwo. Również rozmowa z Rytygierem oraz wcześniejsza odpowiedź dana przysłanemu przez niego posłowi eksponuje tę cechę charakteru. Kobieta

${ }^{38}$ Decyzja Wandy dosadnie obrazowała specyficzny status władcy w polskiej tragedii. Król bądź królowa byli gwarantem istnienia ładu w świecie. Zobowiązani byli na mocy sprawowanej funkcji do posłuszeństwa zarówno Bogu, jak i społeczeństwu. To dlatego córka Kraka, doskonale rozumiejąc swoją rolę, ostatecznie odrzuca oświadczyny Rytygiera. Zob. D. Ratajczak, Przestrzenie narodowej tragedii, „Pamiętnik Literacki” 1981, t. LXXII, z. 2, s. 80.

${ }^{39}$ Kobieta czyni nawet sobie wyrzuty, że mogła w ogóle rozważać porzucenie tronu: „[...] Kiedy do steru rządów Polska mię wezwała. / Temu obowiązkowi poświęcona cała / Powinnam, przytłumiając srogie serca bicie. / Poświęcić mu swą miłość, a nawet i życie [...] / Co za wstyd dla mnie! jaka hańba dla Narodu! / Gdybym ważyć się mogła z takiego powodu / Obalać prawa polskie, i zakładać sobie / Korzyść własnego szczęścia na wolności grobie? [...]" (a. I, s. 4, ww. 213-222). Cytaty pochodzą z tomu: T. Łubieńska, Wanda, Warszawa 1927.

${ }^{40}$ H. Mortkowicz-Olczak, op. cit., s. 30.

${ }^{41}$ Urodę Wandy eksponowały przekazy kronikarskie. W Kronice wielkopolskiej z tą cechą związana była etymologia jej imienia: „Piszą bowiem, że miała tyle powabu i wdzięku, że niezwykle ujmującym swym wyglądem wzbudzała ku sobie miłość wszystkich, którzy na nią patrzyli; dlatego właśnie nazywano ją Wanda, to jest węda". Kronika wielkopolska, tłum. J. Sękowski [w:] By czas nie zaćmit i niepamięć. Wybór kronik średniowiecznych, oprac. A. Jelicz, Warszawa 1975, s. 95. 
niezwykle stanowczo odpiera groźby księcia. Perspektywa wybuchu wojny zdaje się jej nie przerażać:

[...] Może ziemia przed ciosem Rytgiera stęknie,

Może zadrżą sąsiady, lecz Wanda nieklęknie!

To mnóstwo zgromadzone zbrojnych Markomanów,

Którem Książe chce moich pokonać ziemianów,

Do czynności mych dalszych nie będzie ustawą.

Nikt mnie jeszcze bezkarnie niedyktował prawo.

Krew Niemiecka wprzód nurty Wisły zarumieni,

Niźli krokiem postąpią w Sarmackiej przestrzeni [...]

(I, s. 2, ww. 204-211)

Pomimo tych słów ostatecznie to Przemysław prowadzi do walki armię, Wanda zaś pozostaje na jego polecenie w zamku. Burzy to trochę obraz odwagi królowej, jaki budowany był na początku utworu ${ }^{42}$. Na koniec przemawia znów kobieca delikatność, która każe władczyni trzymać się z daleka od rozlewu krwi. $\mathrm{W}$ wypowiedziach, w których bohaterka wspomina o zbrojnym rozwiązaniu konfliktu z Rytygierem, da się zauważyć interesujący fakt: otóż córka Kraka w pierwszej kolejności mówi o tym, że nie wyobraża sobie, by mogła poślubić człowieka, który jest jej sercu niemiły. Dopiero później zastanawia się nad wynikającymi z podjęcia takiej decyzji konsekwencjami:

[...] Wolę walczyć z sąsiadem, jak się lękać męża.

Cóżbym sobie za szczęście zjednała przy ślubie!

Jakbym mogła z człowiekiem żyć, co go nie lubię?

A choćbym na ostatek z przymusu fałszywa,

Wprzęgła się w te nieszczęsne z Książęciem ogniwa,

Czy te srogie dla serca mojego zamęście

Licznych by mych poddanych utwierdziło szczęście? [...]

(I, s. 3, ww. 241-247)

Wanda jest przede wszystkim zakochaną, nieszczęśliwą kobietą, a dopiero później królową. Z jej kwestii wyłania się hierarchia wartości inna, niż było to w przypadku Wandy Łubieńskiej. Podczas gdy w poprzednim utworze poczucie obowiązku oraz odpowiedzialności za losy kraju zwyciężyły w wewnętrznym konflikcie, tak tutaj dobro poddanych zawsze znajduje się na drugim miejscu. Wanda Rościszewskiego skupia się przede wszystkim na własnych uczuciach i swoim prywatnym dramacie. Zastanawiająca okazuje się jeszcze jedna kwestia. Na początku królowa wydaje się w pełni świadoma tego, że Wszewor z Arcykapłanem starają się kierować jej poczynaniami, by osiągnąć własne cele:

${ }^{42}$ Kłóci się to również z wersją znaną z podania, w której pojawienie się Wandy na polu bitwy było kluczowe. Według Wincentego Kadłubka wojownicy Rytygiera onieśmieleni urodą królowej wycofali się bez walki: „Skoro tylko bowiem wojsko jego ujrzało naprzeciw królową, nagle rażone zostało jakby jakimś promieniem słońca: wszyscy jakoby na jakiś rozkaz bóstwa wyzbywszy się wrogich uczuć odstąpili od walki; twierdzą, że uchylają się od świętokradztwa, nie od walki; nie boją się [mówili] człowieka, lecz czczą w człowieku nadludzki majestat" (W. Kadłubek, Kronika polska, tłum. B. Kürbis, Wrocław 2003, s. 17-18). Łubieńska, w przeciwieństwie do Rościszewskiego, przenosi tę scenę, w wersji niemal literalnej, do swojej tragedii. 
[...] Ale znam ja Wszewora i Arcykapłana,

Jak ich niechęć jest cnoty powłoką przywdziana:

Oni pod dobra kraju zmyślonym pozorem

Chcą państwem, mą osobą, i mym rządzić dworem [...]

(I, s. 1, ww. 15-18)

Zdawać by się mogło, że Wanda, będąc świadoma zagrożenia ze strony tej dwójki, powinna zwracać baczniejszą uwagę na poczynania obydwu. Tymczasem jakby zapomina o negatywnych uczuciach żywionych wobec niej i nie podważa ani autentyczności rzekomej przepowiedni Arcykapłana, ani jego późniejszych doniesień o śmierci Przemysława. Nie ma momentu zawahania czy namysłu z jej strony, choć wydawałoby się to logiczne w świetle jej pierwszych refleksji. Kobieta wierzy każdemu słowu Arcykapłana, dając mu kierować swoimi poczynaniami. Zastanawiające jest, co kryje się wtedy za działaniami córki Kraka. Czy ufność bogom i strach przed ich urażeniem sprawiają, że nie śmie ona kwestionować słów Arcykapłana wypowiadanych w świątyni? Jeśli nawet jest to prawidłowa hipoteza, to pozostaje jeszcze kwestia końcowych scen. Czy za wiarą w domniemaną śmierć Przemysława stało przede wszystkim przeświadczenie o prawdziwości usłyszanej przepowiedni, według której jedno z trojga, Wanda, Rytygier bądź Przemysław mieli ponieść śmierć?

Wydaje się, że bohaterka, popełniając samobójstwo, działa przede wszystkim pod wpływem impulsu. Kieruje nią żal za utraconą miłością, jednak jej śmierć jest zupełnie inaczej odbierana niż śmierć w Wandzie Łubieńskiej. W tamtym przypadku królowa targa się na swoje życie tuż po wygranej bitwie z Niemcami, kiedy zagrożenie z ich strony zostaje zażegnane, a Polakom zapewniony jest pokój. Wanda odchodzi dopiero gdy wywiąże się wcześniej ze swych obowiązków monarszych. Można powiedzieć, że z czystym sumieniem chce połączyć się pośmiertnie z ukochanym. Tymczasem u Rościszewskiego kobieta rzuca się do Wisły, usłyszawszy wiadomość o rzekomej śmierci Przemysława. Jeśli byłaby to informacja prawdziwa, w takim przypadku wojsko polskie pozostałoby bez przywódców, a niemieckie w dalszym ciągu posiadałoby swojego wodza. Zagrożenie byłoby wciąż realne. Śmierć Wandy jest więc aktem rozpaczy kochanki, który zupełnie nie przystoi władczyni. Powinna jako królowa w pierwszej kolejności zadbać o bezpieczeństwo swojego kraju, a następnie myśleć o własnych uczuciach. Wcześniejsze wypowiedzi córki Kraka zdają się potwierdzać takie odczytanie. Wanda - po raz pierwszy po usłyszeniu przepowiedni, a później, kiedy na początku walki Rytygierowi udaje się uciec - skłania się ku popełnieniu samobójstwa, by uchronić przed śmiercią Przemysława:

Tak, najwyższych wyroków niezwrotnym rozkazem,

Ogłoszona jest wojna, i śmierć moja razem.

Mój zgon przepowiedziany jest szczęścia zakładem,

Gdy zwycięskim do niego postępuje śladem.

Cóż, że mnie śmierć wymaże z żyjącego świata,

Lepiej przeżyć wieki, aniżeli lata. -

A z rzędu wyłączona, tej karty ogólny,

Odbędę ten choć wczesny krok, lecz dobrowolny [...]

(III, s. 9, ww. 313-320) 
Od podjęcia tego kroku powstrzymuje ją jedynie Przemysław, który deklaruje pokonanie Rytygiera i tym samym wypełnienie przepowiedni. Decyzja, z jaką nosiła się Wanda, przystoi kochance, lecz nie władczyni. Ostatecznie nie można przypisywać ofiarnej roli śmierci córki Kraka w tym utworze. Jej skok do rzeki jest czynem ogarniętej żalem kobiety, która ma nadzieję, że pośmiertnie zespoli się z ukochanym. Podsumowując, Rościszewski zrezygnował z uczynienia z postaci legendarnej królowej symbolu walk z zaborcami. Chociaż Wanda u dramaturga również odrzuca ofertę małżeństwa ze strony Rytygiera, czyni to głównie motywowana własną niechęcią do księcia, nie zaś dobrem ojczyzny. Tragedia bohaterki Rościszewskiego to tragedia zakochanej kobiety, której przeciwności losu nie pozwalają na szczęśliwe życie u boku wybranka.

Warto przyjrzeć się także bohaterom męskim. Sposób, w jaki został przedstawiony Przemysław, ma w sobie wiele z portretu Rytygiera Łubieńskiej. Wydaje się, że takiemu sposobowi konstrukcji bohatera przyświecał taki sam cel, jak w przypadku pierwszej tragedii. Przypisanie Przemysławowi szeregu zalet niejako ma usprawiedliwiać uczucia Wandy. Polski wódz kreowany jest na wzór cnót. Wyróżnia się męstwem oraz roztropnością, co sprawia, że królowa powierza mu dowództwo nad swoją armią. W końcowym starciu z Niemcami Przemysław zyskuje także cechy podaniowej Wandy. To jego działania zapewniają Polakom zwycięstwo. Sama córka Kraka często zasięga jego rady, ceniąc jego mądrość. Przemysław zdaje sobie sprawę z tego, że Wanda nie może pojąć go za męża. Mimo to nie opuszcza jej i wszystkimi siłami umacnia jej rządy. Rycerz przez cały czas żywi nadzieję, że zdoła znaleźć rozwiązanie, które pozwoli mu połączyć się z ukochaną węzłem małżeńskim.

W zupełnie innym świetle prezentuje się postać Rytygiera. Sportretowany przez Rościszewskiego książę nie przypomina bohatera Łubieńskiej ${ }^{43}$ - znacznie bliżej mu do postaci znanej z kronik. To gwałtownik i okrutnik, który na odmowę reaguje agresją. Nie wydaje się godny ręki Wandy. Jego zamiar poślubienia polskiej królowej wynika przede wszystkim z chęci poszerzenia granic własnego państwa:

[...] Wiesz, że sąsiad łakomy, a może i tkliwy,

Chce się z tobą połączyć ślubnemi ogniwy.

Od dawna pragnąc zdobyć płodne zbożem strony,

Ku Księżnie Nadwiślanów ma umysł zwrócony [...]

(I, s. 1, ww. 45-48)

Kiedy jego oświadczyny nie zostają przyjęte, zawiązuje sojusz z Wszeworem i Arcykapłanem. Z podania Rościszewski postanowił zachować motyw rzucanej przez księcia klątwy oraz jego samobójczej śmierci. Nie ma ona jednak ukrytych,

${ }^{43}$ Trzeba zaznaczyć, że idealizacja postaci Rytygiera była znamienna dla tych Wand, które opierały się na wątku miłości polskiej królowej do niemieckiego księcia. Mężczyzna godny miłości Wandy nie mógł być przedstawiany w sposób negatywny, gdyż rzutowałoby to na wizerunek samej bohaterki. Zob. H. Mortkowicz-Olczak, op. cit., s. 28. 
dodatkowych aluzji, jak to było w przypadku Łubieńskiej ${ }^{44}$ - jej treść jest zgodna $\mathrm{z}$ tą, która została zachowana w kronikach:

\section{BOLESTA}

[...] A wy co wzgardziliście Książęcia rozkazem!

Zuchwali buntownicy, lecz nikczemni razem,

Zbierzcie owoce waszej bezbożnej nauki,

Niechby wasi synowie, niechby wasze wnuki,

Sami sobie dać rady nie umiejąc, wreszcie,

Innych praw nie miewali, jak rządy niewieście [...]

(IV, s. 1, ww. 86-91)

Powód porażki wojska Rytygiera zostaje jednak znacznie zmieniony. Nie dochodzi do niej po pojawieniu się na polu bitwy Wandy, której obecność według dziejopisarzy jakby sparaliżowała wojowników nieprzyjaciela. U Rościszewskiego Niemcy wydają się nie mieć serca do tej wojny, która ich zdaniem jest niesprawiedliwa:

\section{PRZEMYSŁAW}

[...] Lecz nie wiem, czy to wola Bogów niedościgła

Ochota nawet w Niemcach do bitwy ostygła.

Porzucili na miejscu, i tarcze i piki,

I bez trudu ich nasze wzięły wojowniki.

(III, s. 9, ww. 309-312)

Tym, co także różni obie Wandy, jest brak u Rościszewskiego bohatera zbiorowego, jakim są Polacy ${ }^{45}$. Zamiast niego otrzymujemy dość zróżnicowaną grupę, w skład której wchodzą dwie dwórki Wandy: Oda i Wiola, Przemysław oraz Wszewor i Arcykapłan. Dwaj wymienieni na końcu bohaterowie zaprzeczają budowanemu dotychczas w literaturze obrazowi charakteru narodowego Polaków. Zawiązują oni z Rytygierem spisek, który początkowo ma doprowadzić do małżeństwa księcia z Wandą, a ostatecznie do śmierci jej oraz Przemysława. Intryga podważa więc taką domniemaną cechę narodową, jak pogarda dla zdrady ${ }^{46}$.

${ }^{44} \mathrm{O}$ ile u Łubieńskiej pierwsze wersy są zgodne z przytaczanymi przez kroniki słowami klątwy, o tyle od wersu $340 \mathrm{w}$ słowach księcia ówczesny widz mógł z łatwością odnaleźć nawiązania do sytuacji Prus: ,„[...] A kiedy użyjecie chytrości, nie męstwa, / Obyście, rządząc kraje przez podstęp zabrane [...] / Odbierali nienawiść w grabieży zamianę [...] / Niech kiedyś na ościennym zagnieździ się łonie / Ten mściwy nieprzyjaciel, który was pochłonie [...]” (a. V, s. 11, ww. 340-344).

${ }^{45}$ U Łubieńskiej bohater zbiorowy jest konsekwentnie budowany przy wykorzystaniu stereotypu „sielskiego Słowianina”. Polacy ukazują się jako lud szlachetny, słynący z umiłowania pokoju i wolności. Do końca starają się rozstrzygnąć konflikt bez uciekania się do rozlewu krwi. Cenią swobodę obywatelską, co wiąże się z niechęcią oddania korony Rytygierowi. Pomimo spokojnego charakteru w obliczu zagrożenia są gotowi mężnie bronić ojczyzny. Śmierć za kraj poczytują sobie za powód do chwały.

${ }^{46}$ Niezgoda na zdradę, nawet jeśli jest to zdrada mająca ściągnąć zgubę na nieprzyjaciela, zostaje wyeksponowana u Łubieńskiej: „STARŻA / Przełożyłem żądanie, lecz jeśli mam radzić, / Polak nieprzyjaciela nie powinien zdradzić; / Odrzuciłbym bez względu ten zamiar Kaslerza, / Chociaż dla dobra kraju w celu swoim zmierza. / Nie - pozwolić nie można na młodzieńca chęci [...]” (a. III, s. 1, ww. 143-147). 
Ostatecznie Wszewor wycofuje się ze współpracy z Niemcami, tłumacząc podejmowane dotychczas działania wyłącznie dobrem kraju:

Nie wiedziałem, co jeszcze dla kraju wypadnie;

Widziałem co twój zamysł tajemnie układa,

A przyjaźń mi się zdała potrzebną sąsiada -

I w obieraniu męża, naglącej potrzebie,

Wolałem wszystkich minąć, niż przybliżyć ciebie [...] [Przemysława]

(III, s. 8, ww. 240-244)

Arcykapłanem natomiast zdaje się kierować jedynie nieuzasadniona nienawiść do królowej oraz żądza władzy. By zgubić Wandę, ucieka się do sfałszowania przepowiedni. Czyni to w świątyni, w obliczu bogów, którym powinien służyć. Pokazuje to, że mężczyzna jest w stanie zrobić wszystko, by zniszczyć królową. Dopiero doprowadzony do ostateczności, wyznaje swoje winy przed Przemysławem.

Dzięki intrydze Wszewora i Arcykapłana całość nabiera sensacyjnego wymiaru. Wprowadzenie tego wątku wydłuża czas trwania utworu. Gdyby Rościszewski ograniczył się wyłącznie do wykorzystania wydarzeń zawartych w podaniu, akcję należałoby rozwiązać po przegranej Niemców i śmierci Rytygiera. Tymczasem wydarzenia rozwijają się jeszcze po tym, jak bohaterowie dowiadują się o zgonie księcia. Mortkowicz-Olczakowa wskazuje, że wprowadzenie tego wątku było konieczne ${ }^{47}$. Rościszewski po zminimalizowaniu obecności motywów patriotycznych na ich miejsce musiał wprowadzić inne. Wykluczenie jednego z istotniejszych elementów i niezastąpienie go niczym zniosłoby efekt tragizmu. Wprowadzenie postaci czarnych charakterów, które zawiązują przeciwko bohaterce intrygę, jest jednym ze sposobów na wypełnienie powstałej luki ${ }^{48}$.

Przywołane utwory opierające się na podaniu o Wandzie stanowią jedynie mały wyimek obszernej twórczości poświęconej legendarnej królowej. Już jednak ten niewielki ułamek doskonale pokazuje uniwersalizm historii i konterfektu córki Kraka. Chociaż Rościszewski i Łubieńska na pierwszy rzut oka dokonali bardzo podobnej modyfikacji w podaniu o Wandzie (dodanie wątku miłosnego), przy zachowaniu w większości głównego przebiegu zdarzeń, osiągnęli zupełnie inne efekty końcowe. Łubieńska jest zdecydowanie bliższa oryginalnej opowieści niż Rościszewski, przez sposób portretowania głównej bohaterki. Najważniejszą różnicą jest jednak wymowa utworu. O ile w dziele pisarki można odnaleźć szereg elementów odsyłających bezpośrednio do ówczesnych wydarzeń, o tyle tragedia Rościszewskiego zdaje się mieć charakter rozrywkowy z sentymentalnym rysem $^{49}$. Uważam, że nie należy doszukiwać się w jego Wandzie dodatkowych funkcji związanych z pobudzaniem uczuć narodowych. Dramaturg postanowił pokazać historię legendarnej królowej w zupełnie nowym świetle. Zamiast koncentrować się na próbie aktualizacji podania i odniesienia go do sytuacji, w jakiej znalazł się polski naród, przede wszystkim starał się ukazać dramat kobiety, na

${ }^{47}$ H. Mortkowicz-Olczak, op. cit., s. 25-26.

${ }^{48}$ Motyw ten wykorzystują w swoich Wandach również Euzebiusz Słowacki oraz Jan Ignacy Dembowski. Ibid., s. 26.

${ }^{49} \mathrm{Na}$ co wskazuje chociażby sposób skonstruowania tytułowej bohaterki. 
której barki włożono ogromną odpowiedzialność, a która niekoniecznie potrafi sobie z nią poradzić. Jego Wanda może nie wzbudzać takiego szacunku i podziwu jak Wanda Łubieńskiej, ale z pewnością jest bardziej ludzka - przez to, że tak daleko jej do ideału, staje się bliższa czytelnikowi w warstwie psychologicznej

Chociaż polskie oświecenie literackie usankcjonowały głównie dzieła stawiające sobie za cel pobudzanie uczuć narodowych, nie należy zapominać, że równolegle powstawały utwory niemieszczące się w tych schematach normatywnych. Niektórzy autorzy mieli zupełnie inny pomysł na interpretację podań i przekazów historycznych. Wanda Rościszewskiego otwiera nowoczesną galerię postaci tragicznych, wyznaczając w jakiejś mierze kierunek temu, co z czasem wyłoni się jako projekt intymizacji teatru ${ }^{50}$. $\mathrm{Z}$ całą pewnością jest też przykładem ilustrującym, jak szeroki może być wachlarz możliwości interpretowania dziejów bajecznych.

\section{Bibliografia}

Banaszkiewicz J., Polskie dzieje bajeczne mistrza Wincentego Kadtubka, Wrocław 1998.

Bartkiewicz K., Obraz dziejów ojczystych w świadomości historycznej w Polsce doby Oświecenia, Poznań 1979.

Czartoryski A.K., Przedmowa do Panny na wydaniu [w:] Teatr Narodowy 1765-1794, red. J. Kott, Warszawa 1967.

Czwórnóg-Jadczak B., Klasyk aż do śmierci. Twórczość literacka Franciszka Wężyka, Lublin 1994.

Gieysztor A., Mitologia Stowian, oprac. A. Pieniądz, Warszawa 2006.

Golański F.N., O wymowie i poezji, Wilno 1808.

Grabski A.F., Myśl historyczna polskiego oświecenia, Warszawa 1976.

Hoffman A., Heligunda, Warszawa 1929.

Kadłubek W., Kronika polska, tłum. B. Kürbis, Wrocław 2003.

Kronika wielkopolska, tłum. J. Sękowski [w:] By czas nie zaćmit i niepamięć. Wybór kronik średniowiecznych, oprac. A. Jelicz, Warszawa 1975.

Łubieńska T., Wanda, Warszawa 1927.

Maślanka J., Literatura a dzieje bajeczne, Warszawa 1984.

Maślanka J., Słowiańskie mity historyczne w literaturze polskiego oświecenia, Wroclaw 1968.

Mortkowicz-Olczak H., Podanie o Wandzie. Dzieje wątku literackiego, Warszawa 1927.

Paprocki B., Herby rycerstwa polskiego przez Bartosza Paprockiego zebrane $i$ wydane r. p. 1584; wydanie Kazimierza Józefa Turowskiego, Kraków 1858.

Ratajczak D., Polska tragedia neoklasycystyczna, Wrocław 1988.

Ratajczak D., Wstęp [w:] Polska tragedia neoklasycystyczna, Wrocław 1988.

Ratajczak D., Przestrzenie narodowej tragedii, „Pamiętnik Literacki” 1981, t. LXXII, z. 2 , s. $43-82$.

${ }^{50}$ Por. D. Sajewska, „Chore sztuki” - choroba, tożsamość, dramat. Przemiany podmiotowości oraz formy dramatycznej w utworach scenicznych przełomu XIX i XX wieku, Kraków 2005. 
Rościszewski A., Do czytelnika [w:] A. Rościszewski, Wanda, Kraków 1810.

Rościszewski A., Wanda, Kraków 1810.

Sajewska D., „Chore sztuki” - choroba, tożsamość, dramat. Przemiany podmiotowości oraz formy dramatycznej w utworach scenicznych przełomu XIX i XX wieku, Kraków 2005.

Szyjkowski M., Dzieje nowożytnej tragedii. Typ pseudoklasyczny (1661-1831), Kraków 1920.

Ujejski J., Wstęp [w:] Wanda, T. Łubieńska, Warszawa 1927.

Wierzbicki A., Historiografia polska doby romantyzmu, Wrocław 1999.

Zieliński A., Czy smok wawelski byt człowiekiem? Historia polskich legend, Warszawa 2016. 